\title{
Palatalization Practices in Ghanaian English
}

\author{
Kingsley Cyril Mintah ${ }^{1, *}$ \\ ${ }^{1}$ General Studies Department, Wisconsin International University College, Ghana \\ *Correspondence: General Studies Department, Wisconsin International University College, P. O. Box YK 655, \\ Kanda - Accra, Ghana. Tel: 233-243-804-089. E-mail: kcmintah@yahoo.com
}

Received: February 20, 2015 Accepted: March 22, 2015 Online Published: May 4, 2015

doi:10.5430/wjel.v5n2p9 URL: http://dx.doi.org/10.5430/wjel.v5n2p9

\begin{abstract}
This paper adds to the literature on the phonology of Ghanaian English. The paper focuses on describing the assimilation process of palatalization which is a feature in the coarticulation of speech sounds in a language variety. The assumption that non-native varieties of English are distinct and unique at all levels of language analysis is used as approach in observing the occurrence of palatalization processes in the data which consisted of informal speech in focus group discussion, and formal reading of word lists and a passage. The study shows that generally place-changing palatalization processes like velar softening, spirantization and coronal palatalizations are established features in Ghanaian English though coronal palatalization of the voiced alveolar stop [d] to the voiced palato-alveolar affricate [d] does not occur. Also, yod-insertion palatalization is greatly influenced by the length of the following high vowel. Yod-insertion palatalization frequently occurs with the labials [f], [m], and [b] and the alveolars [t] and [d]. Nevertheless, the labial [p], the alveolars [1], $[\mathrm{s}]$ and $[\mathrm{n}]$ and the velar stops $[\mathrm{k}]$ and $[\mathrm{g}]$ are hardly palatalized in Ghanaian English. Significantly, palatalization is a local assimilation feature which tends to be regressive in direction. Word boundary palatalization frequently occurs among fricatives.
\end{abstract}

Keywords: assimilation; palatalization; yod-insertion; spirantization; coronals; Ghanaian English

\section{Introduction}

As a linguistic fact, non-native varieties of English exist and many scholars [Kachru (1988, 1992), Görlach (1988), Ahulu (1994), Bamgbose (1997), Dako (2001a), Schneider (2003, 2014), among others] have written extensively on these varieties of English. Earlier scholars like Halliday, MacIntosh and Strevens (1964: 293) have noted that English 'is no longer the possession of the British, or even the British and the Americans, but an international language which increasing numbers of people adopt for at least some of their purposes, without thereby denying ... the value of their own languages.' This assertion is made on the basis that as a language is transported from one region or geographical location to the other, changes occur in its grammatical, phonological, semantic and pragmatic use.

Recent studies by Schneider $(2003,2014)$ have provided more extensive account of the emergence of New Englishes. Schneider $(2003,2014)$ by his 'Dynamic Model' of the evolution of New Englishes has explained that New Englishes go through five phases of development: Foundation, Exonormative stabilization, Nativization, Endonormative stabilization and Differentiation. The Foundation phase describes the stage where through colonial expansion or otherwise, English is established in a new territory, while the Exonormative stabilization phase describes the acceptance of English by indigenes due to political stabilization of the territory as a colony. Ghana acquired the English Language in the colonial times for formal discourse and has since appropriated it as a link language which bridges the gap of communication between speakers of different ethnic languages in the country. It is generally known that Ghana has enjoyed the longest tutelage under the British rule because the Gold Coast (Ghana) entered into treaty relations with the English earlier than any other Anglophone country in the West African sub-region (Quarcoo 1994). English has since remained the de facto official language of the country and enjoys prestige in Ghana. Thus, Ghanaian English can be said to have gone through the Foundation and Exonormative stabilization phases as a New English.

According to Schneider (2003, 2014), it is at the Nativization phase that linguistic transformations at all levels in the newly evolving variety via Second Language Acquisition, L1 transfer and innovations occur. Owusu-Ansah (1997) 
emphasizes that nativization often leads to recognition of transplanted varieties and their eventual acceptance as independent varieties of a language. It can be argued that the English language used in Ghana has been nativized by Ghanaians and that a careful examination of the phonetics and phonology, the morphology, the lexicon, the syntax, and the stylistics of the language as used by Ghanaians reveals distinctive features which are Ghanaian. Quarcoo (1994:331) underscores this assertion by mentioning that:

We have watched the mouths of Ghanaian speakers of English and come to the firm conclusion that after the language has been with them for over 150 years, the Ghanaian speakers of English have done a few things to it to enable us to label their English a "Ghanaian artefact".

According to the Dynamic Model, the Endonormative stabilization phase is usually reached after political independence when users of the language identify themselves as members of a newly-born variety. It is at this stage where codification of the new variety of English is initiated. Admittedly, Ghanaian English is in transition between the Nativisation and Endonormative stabilization. Huber (2012: 218) echoes this fact and maintains that Ghanaian English 'falls between the Nativisation Phase and the Endonormative Stabilization Phase.' As a new, nativised and developing English, it is significant that the distinctive features of Ghanaian English are fully described and codified. These features have been noted to be established and distinct enough to serve as the variety markers of Ghanaian English.

Though a lot of phonological research works have been carried out in Ghanaian English, none has yet paid particular attention to investigating the process of palatalization; this may be because the literature on the subject in non-native varieties are rare. It is the need to add to the literature on the distinct variety markers of Ghanaian English and also similarities to targeted forms of the Received Pronunciation (RP) that motivates the undertaking of this research. The researcher highlights some general discussions on palatalization in the next section, which is then followed by the researcher's approach to the study, the methodology engaged to conduct the study and the findings of the research.

\section{Literature on Palatalization}

Palatalization is a phonological process by which consonants acquire secondary palatal articulation or shift their primary place towards or close to the palatal region (Kochetov 2010; Ordin 2010). Palatalization occurs between consonants and adjacent front vowels or a palatal glide but in the interaction, it is the vowel or the palatal glide that influences the consonant. All forms of palatalization are triggered by front vowels and may also be triggered by a palatal glide (Halle 2005; Kochetov \& Alderete 2011). Kochetov (2010) maintains that the term palatalization may also refer to a phonemic contrast between consonants with secondary palatal articulation and their non-palatalized counterparts. To Kenstowicz and Kissiberth (1979) palatalization is a feature of tongue body rising to a high front position that approximates the point it assumes in the articulation of the vowel $i$. They observe that among the consonant sounds, velars are most easily palatalized, then dentals and finally labials.

The processes of palatalization have a wide range of manifestations across languages and within a given language. However, according to Kochetov (2010), English has at least three kinds of palatalization processes: coronal palatalization, velar softening and spirantization. Coronal palatalization involves an alternation between alveolars [ $\mathrm{t} d$ $\mathrm{s} z]$ and palato-alveolars $\left[\mathrm{t}, \mathrm{d}, \int, 3\right]$. They involve a change of alveolar sound to a palato-alveolar in the context of [j]. The alveolars (targeted sounds) become more similar in the place of articulation to the segment that triggers the palatalization, [j]. Examples are stated in (1) below:

$\begin{array}{lll}\mathrm{t}-\mathrm{t} f & \text { cap[t]ive } & \text { cap[t] ure } \\ \mathrm{d}-\mathrm{d} \mathrm{s} & \text { frau[d] } & \text { frau[d]]ulent } \\ \mathrm{s}-\int & \text { gra[s]e } & \text { gra[J]ious } \\ \mathrm{z}-\mathrm{s} & \text { plea[z]e } & \text { plea[3]ure }\end{array}$

Velar softening involves the alternation between velar stops, $[\mathrm{k}]$ and $[\mathrm{g}]$, and coronal fricatives or affricates, $[\mathrm{s}]$ and [d] respectively. Palatalization, here, is said to be of a change of velars to coronals triggered by front vowels. The coronal alternants are usually found before certain Latinate or Greek suffixes usually beginning with front vowels. According to Kochetov (2010), it actually involves two non-identical changes - a shift of the voiced velar stop to the palato-alveolar affricate and a shift of the voiceless velar stop to the alveolar fricative. This is illustrated in example (2) below:

$$
\begin{array}{lll}
\mathrm{k}-\mathrm{s} & \text { opa[k] } & \text { opa[s]ity } \\
\mathrm{g}-\mathrm{d} s & \text { analo[g] } & \text { analo[d]Jy }
\end{array}
$$


Spirantization involves a change of stop to fricative before high front vowel. It exhibits alternations between the alveolar stop $[\mathrm{t}]$ and the alveolar fricative $[\mathrm{s}]$ or $\left[\int\right]$ in conjunction with coronal palatalization. The latter segment always occurs before suffixes with an unsyllabified /i/. Kochetov (2010) explains that the change does not occur in the place of articulation, but rather in continuancy and sibilancy. Examples:

$$
\begin{array}{lll}
\mathrm{t}-\mathrm{s} & \text { secre[t] } & \text { secre[s]y } \\
\mathrm{t}-\mathrm{s} & \text { Egyp[t] } & \text { Egyp[S]ian }
\end{array}
$$

Abercrombie (1967) describes the above mentioned occurrences of palatalization as 'historical'. In his view, these features are historical because the changes in the words have been established over the period of time. Hence, non-native speakers often learn and accept them into their language with less modification. Haeri (2010) considers them as strong palatalization as they most often lead to affrication.

Another form of palatalization involving the assimilation of a consonant to a vowel results in the insertion of a transitional $j$ off-glide between the consonant and the vowel. This kind of assimilation is also considered as palatalization since there is an attraction towards the hard palate or the production of the palatal [j] although the resulting sound may not necessarily be an affricated consonant. Kochetov (2010) is of the view that this kind of palatalization is not exhibited by the English processes but much more in Russian because it involves an addition of secondary palatal articulation, without a change in primary place or assibilation. However, there is evidence in English that this form of palatalization exists though the resulting sound is not phonemic as it is in Russian. Haeri (2010) describes these types as weak palatalization since the effect is one of frication. In this research, I refer to this type of palatalization as yod-insertion palatalization. Examples are stated in (4) below:

$$
\begin{array}{ll}
\text { regular } & \rightarrow \mathrm{re}[g j] \text { ular } \\
\text { circulate } & \rightarrow \mathrm{cir}[k j] \text { ulate } \\
\text { accuracy } & \rightarrow \mathrm{a}[\mathrm{kj}] \text { uracy } \\
\text { commune } & \rightarrow \mathrm{co}[m j] \text { une }
\end{array}
$$

Katamba (1996) observes that palatalization does not only occur at word level as the examples above seem to suggest but can also occur at word boundaries where conditions for its occurrence, as described above, are present. Examples:

$$
\begin{aligned}
& \text { his shoes } \left.\quad \text { [hiz } \int \mathrm{uz}\right] \quad \rightarrow\left[\mathrm{hiz} \int \mathrm{uz}\right] \\
& \text { John's shorts } \quad \text { [dzpnz Jots] } \rightarrow \text { [dzpnz Jots] }
\end{aligned}
$$

\section{Approach}

This work is largely descriptive and attempts to provide a description of this process as manifested in Ghanaian English. The researcher, recognising that non-native varieties of English undergo nativisation processes at most level of analysis to define them as new varieties, assumes that the occurrence of the assimilation process under study will be distinct and influenced by the sociocultural context, as underscored by Bamgbose's (1997) sociolinguistic approach which explores the description of a variety with regards to its contextual use and adaptation. The approach suggests that researchers should acknowledge natural observable outputs or findings as defining varieties whether they conform to native standards or not.

The adoption of the sociolinguistic approach is consistent with the researcher's view that the phonological processes in the phonology of Ghanaian English are largely unique as they may violate certain established descriptions of palatalization by Received Pronunciation with regards to how and when they should occur. It is argued, in this work, that the blocking of this phonological processes where expected in RP and the assimilation of this process where unexpected in RP are contributing characteristics that help in identifying the English used by Ghanaians as Ghanaian English.

\section{Method}

The description of an acceptable non-native variety of English is largely a consideration of the English of the educated speakers of the language and in this case 'educated Ghanaians'. It is with this in mind that the researcher selected students of the tertiary level of education as participants for this research and considered them appropriate for the study since they can be aptly described as educated Ghanaians. Twenty (20) University of Ghana students were randomly but purposefully selected for the research. Of the twenty, ten (10) were male and ten (10) were 
female and they were between the ages of 21 to 42 years. Though this work does not discuss the sociolinguistic impact of gender as a variable on palatalization process, the selection of both male and female participants was deliberately done to ensure that the data could include a fair reflection on responses by both sex as the researcher finds it necessary in the discussion of standard realization of the process in Ghanaian English. Nevertheless, a careful consideration was also made to select both (Note 1) Kwa and Non-Kwa-speaking Ghanaians to fairly represent the Ghanaianess of the response. All the participants, independently and in the comfort of their rooms, read word-lists of twenty words which could elicit the occurrence of palatalization. Also, they engaged in the reading of a passage which was carefully constructed to accommodate the contextual features of the assimilation process. The participants also engaged in focus group discussions which were designed to engage participants in free speech and also allow the researcher, after recording and transcribing the data, to observe the palatalization process.

\section{Findings}

The data suggests that palatalization is an established phonological feature in Ghanaian English manifested in place-changing palatalization, yod-insertion palatalization and palatalization at word boundaries. These exist with notable innovations or distinctiveness which can be attributed to the variety.

\subsection{Place-changing Palatalization}

The study suggests that Ghanaian English largely show similar realisations of place-changing palatalization (coronal palatalization, velar softening, and spirantization(Note 2)) when compared to targeted form of RP. It involves palatalization resulting in a posterior coronal (alveo-palatals) and also palatalization resulting in an anterior coronal (alveolar or dentals) and usually produces either non-sibilants or sibilants. In English, the target consonant sounds of place-changing palatalizaion processes are often coronals and dorsals.

All the participants, representing $100 \%$ of the respondents, engaged in coronal palatalization of the voiceless alveolar plosive $[t]$ to the voiceless alveo-palatal affricative [t] in words. The same can be said to the palatalization of the alveolars [s] and [z] to the alveo-palatals [J] and [3] respectively. Examples of such realisations are illustrated in example (6).

$\begin{array}{llll}\text { Word } & \text { Realisation } & \text { Word } & \text { Realisation } \\ \text { capture } & \text { ['kaptfa] } & \text { gracious } & \text { ['grefios] } \\ \text { creature } & \text { ['kretfa] } & \text { pleasure } & \text { ['pleza] }\end{array}$

Again, all the participants engaged in velar softening palatalization of the velar stops $[\mathrm{g}]$ and $[\mathrm{k}]$ to the coronal voice affricate $[\mathrm{d}]$ and the coronal voiceless fricative [s] respectively when followed by high front vowels of suffixes. This is exemplified in (7).

$\begin{array}{llll}\text { Word } & \text { Realisation } & \text { Word } & \text { Realisation } \\ \text { Criticize } & \text { ['kritisaiz] } & \text { elasticity } & \text { [Elas'tisiti] } \\ \text { Electricity } & \text { [il\&k'trisiti } \sim \text { ile'trisiti] } & \text { analogy } & \text { [a'nalodzi] }\end{array}$

Spirantization that changes a stop to a fricative before high front vowel of suffixes was also significant in the data. All the participants, $100 \%$ of respondents, palatalized the voiceless alveolar stop [t] to the voiceless alveolar fricative [s] or [S] in conjunction with coronal palatalization. Some of the realisations in the data are highlighted in (8) below.

$\begin{array}{llll}\text { Word } & \text { Realisation } & \text { Word } & \text { Realisation } \\ \text { partial } & \text { ['pafial] } & \text { secrecy } & \text { ['sikrisi] } \\ \text { education } & \text { [Edu'kefin] } & \text { regency } & \text { ['ridzensi] } \\ \text { association } & \text { [asosi'efin] } & \text { emergency } & \text { [E'm3:dzensi } \sim \text { i' m3:dzensi] }\end{array}$

To the researcher, the findings above are expected because non-native speakers, like Ghanaians, often consciously learn these 'historical' forms of palatalization as part of the structure of the 'new' words they acquire from the English language into their variety.

However, a significant distinctive feature of the variety noticed was the change of output forms in the coronal palatalization of the voiced alveolar stop [d] to the voiced alveo-palatal fricative [d] as expected in RP. 17 respondents, representing $85 \%$ of the participants, labialized the expected RP palatalized coronal of voiced alveo-palatal fricative [d] to the anterior voiced alveolar [d]. Samples of such realisations are highlighted in example (9). 
(9)

$$
\begin{array}{ll}
\begin{array}{l}
\text { Word } \\
\text { residual }
\end{array} & \text { Realisation } \\
\text { gradual } & {\left[\mathrm{rc}^{\prime} \mathrm{sid}^{\mathrm{w}} \mathrm{al}\right]} \\
\text { graduate } & {\left[\mathrm{grad}^{\mathrm{w}} \mathrm{al}\right]} \\
& {\left[\operatorname{grad}^{\mathrm{w}} \mathrm{et}\right]}
\end{array}
$$

\subsection{Yod-insertion (secondary) Palatalization}

On yod-insertions, the consonant sounds which undergo this form of palatalization include velars, labials, and alveolars. The findings suggest that insertion of the palatal glide after the dorsals hardly occurs in Ghanaian English which is not the same with the RP. From the data, the voiced and the voiceless velars, [k] and [g], rarely attracted a yod when followed by a high vowel. This pattern was consistent with the response of 15 respondents, representing $75 \%$ of the participants. This is indicated in example (10).

$\begin{array}{llll}\begin{array}{l}\text { Word } \\ \text { secular }\end{array} & \text { Realisation } & \text { Word } & \text { Realisation } \\ \text { calculation } & \text { ['sckula] } & \text { concubine } & \text { ['konkubain] } \\ \text { reticular } & \text { [kalku'lefin] } & \text { coarticulation } & \text { [koatiku'lefin] } \\ \text { cure } & \text { [re'tikula] } & \text { secure } & \text { [si'kij] } \\ \text { accuracy } & \text { ['kij] } & \text { accumulate } & \text { [akumi'let } \sim \text { akum'let] } \\ \text { vehicular } & \text { ['akuresi] } & \text { calculate } & \text { [kalku'let] } \\ \text { porcupine } & \text { [ve'hikula] } & \text { molecular } & \text { [mo'likula] } \\ \text { articulate } & \text { ['pokupain] } & \text { circular } & \text { ['se:kula] } \\ \text { acupuncture } & \text { [atiku'let] } & \text { muscular } & \text { ['maskula] } \\ \text { calculus } & \text { [aku'pontfa] } & \text { ridicule } & \text { ['ridikil] } \\ \text { regular } & \text { ['kalkulos] } & \text { rectangular } & \text { [rek'tangula] } \\ \text { security } & \text { ['regula] } & \text { particular } & \text { [pa'tikula] }\end{array}$

$30 \%$ of the respondents, however, inserted the palatal glides after the voiced and voiceless velar stops in some instances. In these few cases, the length of the vowels that occur after the palatal glide had to be long. This is

\begin{tabular}{|c|c|}
\hline Word & Realisation \\
\hline document & 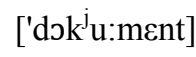 \\
\hline persecution & [pesi'k' $\left.{ }^{\mathrm{j}} \mathrm{u}: \int \mathrm{in}\right]$ \\
\hline electrocute & [ilektro'k $\left.\mathrm{k}^{\mathrm{j}} \mathrm{u}: \mathrm{t}\right]$ \\
\hline arguments & ['ag $\left.{ }^{\mathrm{j}} \mathrm{u}: \mathrm{m} \varepsilon n t s\right]$ \\
\hline
\end{tabular}
indicated in example (11). This feature can be regarded as distinct to the variety as lengthening of the vowel sound is not a condition in for the occurrence yod-insertion in RP.

Yod-insertion after coronals was also observed. Of particular interest was yod-insertion after the alveolar coronal. The voiced alveolar lateral [1], the voiceless alveolar sibilant [s], and the alveolar nasal [n] did not accommodate the insertion of the palatal glide when they were followed by vocoids in the data. This is significantly a distinct characteristic of Ghanaian English as 18 of the participants, $90 \%$, observed this feature. This is illustrated in example

\begin{tabular}{|c|c|c|c|}
\hline $\begin{array}{l}\text { Word } \\
\text { failure }\end{array}$ & $\begin{array}{l}\text { Realisation } \\
{\left[\text { 'felia } \sim \text { 'fel }^{\mathrm{w}} \mathrm{a}\right]}\end{array}$ & $\begin{array}{l}\text { Word } \\
\text { absolute }\end{array}$ & $\begin{array}{l}\text { Realisation } \\
\text { ['absolut] }\end{array}$ \\
\hline dilute & [dai'lut] & cellular & ['sclula] \\
\hline delude & [di'lud $\sim$ d $\left.\varepsilon^{\prime} l u d\right]$ & salutation & [salu'te in] \\
\hline soluble & ['solub $\left.{ }^{\mathrm{u}} 1\right]$ & & \\
\hline Word & Realisation & Word & Realisation \\
\hline capsule & ['kapsu:l] & encapsulate & [En'kapsulet] \\
\hline
\end{tabular}
(12) for the alveolar lateral, example (13) for the voiceless alveolar sibilant and example (14) for the alveolar nasal. 


$\begin{array}{ll}\text { suicide } & \text { [su:'said] } \\ \text { Word } & \text { Realisation } \\ \text { ingenious } & \text { [in'djinios] } \\ \text { enumerate } & \text { [Enum'ret] } \\ \text { opinions } & \text { ['opinions] } \\ \text { continue } & \text { ['kontinio] }\end{array}$

$\begin{array}{ll}\text { pursuant } & {\left[\mathrm{p} \varepsilon^{\prime} \text { 'suant } \sim \mathrm{p} \varepsilon^{\prime} \mathrm{s}^{\mathrm{w}} \text { ant }\right]} \\ \text { Word } & \text { Realisation } \\ \text { continuous } & {[\text { 'kontinios }]} \\ \text { enumerable } & \left.\text { ['inumrab }{ }^{\mathrm{u} l}\right] \\ \text { insinuate } & {\left[\text { insi'n }{ }^{\mathrm{w}} \mathrm{et}\right]}\end{array}$

The findings above suggest that secondary palatalization of the voiced alveolar lateral, the voiceless alveolar sibilant, and the alveolar nasal hardly occurs in Ghanaian English. The word 'hardly' is used because it is the view of the researcher that when GhE speakers choose to lengthen the vocoids after the above mentioned alveolar sounds, secondary palatalization of the sounds is likely to take place. This is evident in the realisation of the secondary palatalization of the voiceless and voiced alveolar stops in examples (15) and (16). Example (15)a represents the response of 13 respondents, that is $65 \%$ of the respondents, and example (16)a represents the response of 15 participants, $75 \%$, who on some occasions chose to lengthen the vowel sounds to accommodate the insertion of the yod. The data emphasises that this kind of palatalization occurs only in the company of long vowels but the yod will not be inserted after the alveolar stops when respondents, by extension Ghanaians, shorten the vowel sounds as illustrated in examples (15)b of 17 respondents, 85\%, and example (16)b of 16 respondents, $80 \%$ of participants.

\begin{tabular}{|c|c|c|c|c|}
\hline \multirow[t]{5}{*}{ (15) a. } & Word & Realisation & Word & Realisation \\
\hline & institute & [insti'tíu:t] & tubeless & ['tubles $\left.\sim^{\prime} \mathrm{t}^{\mathrm{j}} \mathrm{u}: \mathrm{bles}\right]$ \\
\hline & similitude & [simili't'tu:d] & servitude & ['sevit'u:d] \\
\hline & substitute & ['sabstit'u:t] & negritude & ['negrit' $\mathrm{u}: \mathrm{d}$ ] \\
\hline & stupid & ['st'u:pid] & constitution & [konsti't $\left.t^{j} \mathrm{u}: \int \mathrm{in}\right]$ \\
\hline \multirow[t]{3}{*}{ b. } & Word & Realisation & Word & Realisation \\
\hline & constituency & ['kon'stit $\left.{ }^{\mathrm{w}} \mathrm{Ensi}\right]$ & student & ['student] \\
\hline & stupid & ['stupid] & & \\
\hline \multirow[t]{4}{*}{ (16) a. } & Word & Realisation & Word & Realisation \\
\hline & produce & [pro'd $\left.\mathrm{d}^{\mathrm{j}} \mathrm{u}: \mathrm{s}\right]$ & during & ['d $\mathrm{d}^{\mathrm{j}} \mathrm{u}$ :rin] \\
\hline & residue & ['resid $\left.{ }^{\mathrm{j}} \mathrm{u}:\right]$ & dupe & {$\left[\mathrm{d}^{\mathrm{j}} \mathrm{u}: \mathrm{p}\right]$} \\
\hline & undue & ['and'u:] & reduce & {$\left[r^{i^{\prime}} d^{\mathrm{j}} \mathrm{u}: \mathrm{s}\right]$} \\
\hline \multirow[t]{4}{*}{ b. } & Word & Realisation & Word & Realisation \\
\hline & endurance & [en'diorans] & education & 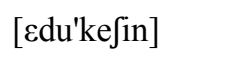 \\
\hline & pendulous & ['pendulos] & individual & [indi'vid $\left.{ }^{\mathrm{w}} \mathrm{al}\right]$ \\
\hline & duplicate & [dupli'ket] & & \\
\hline
\end{tabular}

The same argument can be put forward for the secondary palatalization of labials in Ghanaian English. This is exemplified in the yod-insertion palatalization of the voiced bilabial plosive [b] in (17) and the bilabial nasal in (18). With both labials, the use of long vowels after the labials by the participants allowed the insertion of the palatal glide as exemplified in (17)a of 14 respondents, representing 70\% of the participants, and (18)a of 15 respondents, representing $75 \%$ of the participants. When the participants chose not use the long vowels after the labials, secondary palatalization do not take place as exemplified in (17)b of 16 respondents, representing $80 \%$ of the participants, and (18)b of 17 respondents, representing $85 \%$ of the participants.

\begin{tabular}{|c|c|c|c|c|}
\hline (17) $\mathrm{a}$. & $\begin{array}{l}\text { Word } \\
\text { disabuse }\end{array}$ & $\begin{array}{l}\text { Realisation } \\
\text { [disa'b' }{ }^{\mathrm{j}} \text { u:s] }\end{array}$ & $\begin{array}{l}\text { Word } \\
\text { contributed }\end{array}$ & $\begin{array}{l}\text { Realisation } \\
{\left[\text { kJntri'b }^{j} u: t \varepsilon d\right]}\end{array}$ \\
\hline & distribute & [distri'b $\left.{ }^{\mathrm{j}} \mathrm{u}: \mathrm{t}\right]$ & rebuke & {$\left[\mathrm{ri}^{\prime} \mathrm{b}^{\mathrm{j}} \mathrm{u}: \mathrm{k}\right]$} \\
\hline & tribute & [trib $\left.{ }^{\mathrm{j}} \mathrm{u}: \mathrm{t}\right]$ & debut & [di'b $\left.b^{j} u: t\right]$ \\
\hline b. & Word & Realisation & Word & Realisation \\
\hline
\end{tabular}




\begin{tabular}{|c|c|c|c|c|}
\hline & fabulous & ['fabulos] & fantabulous & ['fantabulos \\
\hline \multirow[t]{3}{*}{ 18) a. } & Word & Realisation & Word & Realisation \\
\hline & commune & ['kJmiju:n] & amuse & [amj $\left.{ }^{\mathrm{j}} \mathrm{u}: \mathrm{s}\right]$ \\
\hline & permutation & [pemu'te $[\mathrm{in}]$ & community & ['kom $\left.{ }^{\mathrm{j}} \mathrm{u}: \mathrm{nit}\right]$ \\
\hline \multirow[t]{2}{*}{ b. } & Word & Realisation & Word & Realisation \\
\hline & stimulant & ['stimulant] & emulate & [Emu'let] \\
\hline & formula & ['fomula] & & \\
\hline
\end{tabular}

One outstanding feature of the variety, Ghanaian English, noted was that the voiceless bilabial plosive showed no case of secondary palatalization. None of the participants engaged in the secondary palatalization of the voiceless bilabial plosive as would be expected in RP. This occurred because speakers avoided the use of long vowels after the labials on any occasion as shown in example (19). It can be said that Ghanaian English does not accommodate yod-insertion after the voiceless bilabial plosive, according to the findings.

$\begin{array}{llll}\text { Word } & \text { Realisation } & \text { Word } & \text { Realisation } \\ \text { punitive } & \text { ['pinitiv] } & \text { stipulate } & \text { [stipu'let] } \\ \text { pupil } & \text { ['pipil] } & \text { deputy } & \text { ['depiti] } \\ \text { manipulate } & \text { [manipu'let] } & \text { copulate } & \text { [kJpu'let] } \\ \text { popularize } & \text { [pjpula'raiz] } & \text { populous } & \text { ['pэplos] }\end{array}$

Nevertheless, the data suggests that secondary palatalization is more expected to occur with the voiceless labiodental fricative in Ghanaian English as shown in (20). Here, $85 \%$ of the respondents inserted the yod before using the long vowel.

\begin{tabular}{|c|c|c|c|}
\hline Word & Realisation & Word & Realisation \\
\hline refugee & [ref'u:'dzi:] & diffuse & [difiu:s] \\
\hline profuse & [pro'f'u:s] & confusion & [kon'f'u:fin] \\
\hline fusion & ['f'u:fin] & future & ['f'u:tfa] \\
\hline funeral & ['f'u:nral] & perfume & [p $\left.\varepsilon^{\prime} \mathrm{f}^{j} \mathrm{u}: \mathrm{m}\right]$ \\
\hline
\end{tabular}

Significantly, what the data emphasises is that the occurrence of yod-insertion/secondary palatalization in Ghanaian English is very much conditioned on the vowel length of the following high vowel after the insertions. For yod-insertion to take place in Ghanaian English, speakers must use long vowels with the yod; hence, when the vowel is shortened, yod-insertion does not take place. Another important assertion is that speakers of Ghanaian English can choose to use or not use a particular yod-insertion feature so long as they use or do not use long vowels; hence, on one occasion, a speaker will use long vowel and insert the yod in a word containing a particular yod-insertion feature but will not use the long vowel with the yod in another word that contains the same yod-insertion palatalization feature. It is also important to note that secondary palatalised consonants are not phonemic in Ghanaian English.

\subsection{Palatalization at Word Boundaries}

The data also suggested that in Ghanaian English, palatalization at word boundaries always occurs with fricatives and are regressive in direction. Here, word final fricatives are palatalized by the influence of a word-initial palatal consonant. In all the cases that word boundary palatalization occurred, it was the word final voiceless dental fricative in 'with you' /wi $\theta$ ju:/ that was palatalised to the voiceless alveo-palatal affricative as in the realisation [wit ju:]. Here the dental fricative palatalizes to the voiceless alveo-palatal affricative due to the influence of the palatal in the word initial 'you'. Word boundary palatalization of voiced and voiceless alveolar fricatives also occurred in the word groups 'release shades'/rili:z Jerdz/, 'nice shoes' /nais fu:s/, and 'always shy'/olweiz fai/ which were represented as /rili: $\int$ Jeds/, /naif Ju:s/ and /alwe $\int$ Jai/. Here, both voiced and voiceless alveolar fricatives palatalize to voiceless alveo-palatal fricative due to the influence of the alveo-palatal fricative in the words initial 'shades', 'shoes' and 'shy'. 


\section{Conclusion}

Linguistic innovations and adaptations are important in the study and description of New Englishes. These established innovations, adaptations or indications of nativizations are linguistic elements that set varieties apart despite the 'Transnational Attraction' (Schneider, 2014) appeal of English. This research has emphasized that as a New English, Ghanaian English maintains some peculiarities in the realization of the assimilation process of palatalization which can be associated with the variety. These findings are very significant to the discussion on the phonology of non-native varieties of English like Ghanaian English as an elaborate description and codification of all assimilation processes that occur in the language can greatly serve as variety markers of new Englishes which in no way undermine the status of English in the world.

\section{References}

Abercrombie, D. (1967). Elements of general phonetics. Edinburgh: Edinburgh University Press.

Ahulu, S. (1994). How Ghanaian is Ghanaian English? English Today, 38, 25-29.

Bamgbose, A. (1997). Non-native English on trial. In M. E. Kropp Dakubu (ed.), English in Ghana. Accra: Black Mask Publishers.

Dako, K. (2001). Ghanaianisms: Towards a semantic and a formal classification. English World Wide, 22. 23-53. http://dx.doi.org/10.1075/eww.22.1.03dak

Ghana Statistical Service. (2012). Population \& Housing Census: Summary Report of Final Results. Accra: Sakoa Press Limited.

Görlach, M. (1988). English as a world language - The state of the art. English WorldWide, 9(1), 1-32. http://dx.doi.org/10.1075/eww.9.1.02gor

Haeri, N. (1994). A linguistic innovation of women in Cairo. Language Variation and Change, 6, 87-112. http://dx.doi.org/10.1017/S0954394500001599

Halle, M. (2005). Palatalization/Velar softening: What it is and what it tells us about the nature of language. Linguistic Inquiry, 36(1), 23-41. http://dx.doi.org/10.1162/0024389052993673

Halliday, M. A. K., McIntosh, A., \& Strevens, P. (1964). The linguistic sciences and language teaching. London: Longman.

Huber, M. (2012). Syntactic and variational complexity in British and Ghanaian English. Relative clause formation in the written parts of the International Corpus of English. In Bernd Kortmann, \& Benedikt Szmrecsanyi (eds.), Linguistic complexity: Second language acquisition, indigenization, contact, 218-242. Berlin: de Gruyter.

Katamba, F. (1996). An introduction to phonology, ( $8^{\text {th }}$ ed.). London and New York: Longman.

Kenstowicz, M., \& Kisseberth, C. (1979). Generative phonology: Description and theory. California: Academic Press Inc.

Kochetov, A. (2010). Palatalization. In: C. Ewen, B. Hume, M. van Oostendorp, and K. Rice (eds.), The Blackwell companion to phonology. Malden, MA: Wiley Blackwell.

Kochetov, A., \& Alderete, J. (2011). Patterns and scales of expressive palatalization: Experimental evidence from Japanese. The Canadian Journal of Linguistics / La revue canadienne de linguistique, 56(3), 345-376. http://dx.doi.org/10.1353/cj1.2011.0028

Ordin, M. (2010). Palatalization and temporal organisation of CVC clusters in Russian. Russian Linguistics, 34(1), 57-65. http://dx.doi.org/10.1007/s11185-009-9049-4

Owusu-Ansah, L. K. (1997). Nativisation and the maintenance of standards in non native varieties of English. In M. E. Kropp Dakubu (ed.), English in Ghana. Accra: Black Mask Publishers.

Quarcoo, E. (1994). The English language as a modern Ghanaian artefact. Journal of Black Studies, 24(3), $329-343$. http://dx.doi.org/10.1177/002193479402400307

Schneider, E. W. (2003). The dynamics of New Englishes: From identity construction to dialect birth. Language, 79(2), 233-281. http://dx.doi.org/10.1353/lan.2003.0136

Schneider, E. W. (2014). New reflections on the evolutionary dynamics of world Englishes. World Englishes, 33(1), 9-32. http://dx.doi.org/10.1111/weng.12069 


\section{Notes}

Note 1. Kwa languages are spoken across the middle and southern parts of Ghana and include Akan, Ga, Dangme, Ewe, Guan, etc. while Non-Kwa languages are spoken in the northern parts of Ghana and include Mole, Dagbani, Grusi, among others. In Ghana, Non-Kwa speakers form the minority of the population accounting for $19.1 \%$ while $80.9 \%$ of the population are Kwa speakers (Ghana Statistical Service, 2012).

Note 2. See (1), (2) and (3) for examples 